\title{
VARIAÇÕES TÉRMICAS: O CASO DAS BACIAS DO AÇUDE E CAPOEIRA EM JATAÍ/GO
}

\author{
MACEDO, Eleida Andrade Garcia - eleidaandrade@hotmail.com \\ MARIANO, Zilda de Fátima - zildamariano@hotmail.com \\ Programa de Pós-Graduação em Geografia \\ UFG - Universidade Federal de Goiás - Campus Jataí
}

\begin{abstract}
RESUMO
O estudo teve como objetivo analisar a variação da temperatura do arda bacia do Açude e Capoeira em Jataí (GO), na escala mensal nos horários das 9h; 15 e 21h. A metodologia pautou-se na teoria desenvolvida por Monteiro (1976) do clima urbano, no subsistema do canal termodinâmico. Foram instalado 6 thermohigrômetros,(área urbana) da bacia do Açude denominados ponto 1 (P1), ponto 2 (P2), ponto 3 (P3), ponto 5 (P5) e ponto 6 (P6), e na bacia do Capoeira(área rural), denominados ponto 7 (P7), ponto 8 (P8), ponto 9 (P9) e ponto 10 (P10), no período de janeiro a dezembro de 2011.Verificou-se que o uso da terra, a hipsometria e a exposição das vertentes, exercem influência na variação da temperatura do ar, na bacia do Açude (urbano) e Capoeira (rural). As temperaturas, máximas, para os horários das 9h, foram maiores na bacia do Açude (urbano); as 15h, as temperaturas máximas foram maiores na bacia do Capoeira (rural); e as $21 \mathrm{~h}$, os maiores valores ocorreram na bacia do Açude. As temperaturas mínimas absolutas mensais foram menores na bacia do Capoeira com uso rural nos horários $9 \mathrm{~h}$ e $21 \mathrm{~h}$, enquanto as $15 \mathrm{~h}$, os maiores valores ocorreram na bacia do Capoeira. Constatou-se que existe uma variação da temperatura do ar, de nas máximas de $42,2^{\circ} \mathrm{C}$ a $23,0^{\circ} \mathrm{C}$; e nas mínimas de $30,9^{\circ} \mathrm{C}$ a $8,1^{\circ} \mathrm{C}$, entre o rural e urbano, nos horários das $9 \mathrm{~h}, 15$
\end{abstract} e 21 horas.

PALAVRAS CHAVES: clima urbano, temperatura do ar, bacias Açude e Capoeira, Jataí.

THERMAL VARIATIONS: THE CASE OF THE BASINS OF THE DAM AND CAPOEIRA IN JATAÍ/GO ABSTRACT

The study had as objective analyzes the variation of the temperature of the air, in the basin of the Dam and Capoeira in Jataí (GO), in the monthly scale in the schedules of the 9:00; 15 and 21:00. The methodology was ruled in the theory developed by Monteiro (1976) of the urban climate, in the subsystem of the thermodynamic channel. 6 urban thermohigrometers, (area were installed) of the basin of the Dam denominated point 1 (P1), point 2 (P2), point 3 (P3), point 5 (P5) and point 6 (P6), and in the basin of the Capoeira (rural area), denominated point 7 (P7), point 8 (P8), point 9 (P9) and point 10 (P10), in the period of January to December of 2011.Verificou-if that the use of the earth, the hipsometry and the exhibition of the slopes, they exercise influence in the variation of the temperature of the air, in the basin of the Dam (urban) and Capoeira (rural). The temperatures, maxims, for the schedules of the 9:00, were larger in the basin of the Dam (urban); the 15:00, the maximum temperatures were larger in the basin of the Capoeira (rural); and the 21:00, the largest values happened in the basin of the Dam. The absolute minimum temperatures monthly were smaller in the basin of the Capoeira with rural use in the schedules 9:00 and 21:00, while the 15:00, the largest values happened in the basin of the Capoeira. It was verified that a variation of the temperature of the air exists, of in the maxims from $42,2^{\circ} \mathrm{C}$ to $23,0^{\circ} \mathrm{C}$; and in the low from $30,9^{\circ} \mathrm{C}$ to $8,1^{\circ} \mathrm{C}$, among the rural and urban, in the schedules of the 9:00, 15 and 21 hours.

KEYWORDS - urban climate, temperature of the air, basins Dam and Capoeira, Jataí.

\section{INTRODUÇÃO}

O clima urbano tem sido palco de grande interesse de pesquisadores, isso devido a urbanização crescente nos últimos anos no Brasil. Principalmente a partir dos anos de 1960 com o êxodo rural e o crescimento das cidades.

Essa mudança no cenário das cidades tem suscitado o interesse em estudar os problemas das cidades médias e pequenas, que também têm suas próprias características de uso e ocupação urbana. O estudo em cidades médias e pequenas nos últimos anos tem aumentado, mesmo com tamanho menor. A 
forma em que muitas cidades são ocupadas traz problemas mesmo de menor dimensão; e assim, seria uma oportunidade de acompanhar o crescimento dessas cidades, preparando para o futuro diminuindo seus problemas.

As investigações sobre o clima urbano tornam importantes; e no Brasil, teve início com Monteiro (1976), a partir das décadas de 60 e 70, baseadas no Sistema do Clima Urbano (S.C.U), que propiciou uma relação entre o físico e o humano, com relação à formação do clima urbano, onde desenvolveu a teria do clima urbano, (MONTEIRO, 1990). Essa teoria do Sistema Clima Urbano (S. C. U) aborda três subsistemas, que se articulam e se integram como: a) o termodinâmico relacionado ao conforto térmico; b) o físico-químico, em relação à qualidade do $\mathrm{ar}$; $\mathrm{c}$ ) e o hidrodinâmico sobre o impacto meteórico (chuvas intensas), (MONTEIRO, 1990, p. 96).

A intensificação da urbanização trouxe a necessidade de estudos do clima urbano, analisando "o uso do solo, a morfologia, os materiais de construção utilizados, desmatamento, entre outros fatores que propiciaram a geração do clima urbano" (PEREIRA e BRANDÃO, 2009, p. 780).

$O$ estudo pioneiro foi realizado na cidade de Florianópolis, desenvolvido por Sezerino e Monteiro (1990), onde constataram que a aglomeração urbana representa maior acúmulo de energia em relação às áreas circundantes. Entre os pontos urbanizados e posto meteorológico, apresentou diferença. A edificação da cidade aliada ao vento podem tomar diferentes direções devido à rugosidade da cidade e interfere no acúmulo de energia acumulada.

Santos e Videira (2010, p. 3) baseado no IBGE (2010), classificam como cidades "pequenas que apresentam população até 100.000 habitantes". As cidades desde o seu surgimento têm apresentado, de acordo com o seu desenvolvimento econômico, mudanças nas formas de uso e ocupação do solo urbano; vários pesquisadores têm realizado estudos do clima urbano em cidades pequenas.

Os estudos realizados em cidades pequenas tem constatado a influência tantos dos fatores da natureza como os antrópicos que atuam em vários ambientes urbanos. Entre esses autores que estudam cidades pequenas posemos citar: Silva (2000) em Penápolis, Freitas et al., (2004) em Jataí, Pinheiro e Amorim (2007) em Euclides da Cunha, Rocha et al., (2007) em Jataí, Lima e Amorim (2009), Viana e Amorim (2009) em Teodoro Sampaio, Souza (2010) em Epitácio - SP, Andrade et al., (2010) em Irati- PR, Lima e Amorim (2011) em Nova Andradina - MS. Ambos os autores constataram de que a ausência de vegetação e concentração de edificações, maior fluxo de veículos e pessoas interferem na temperatura do ar desses lugares.

O crescimento das cidades aumenta as superfícies impermeáveis no perímetro urbano e este crescimento absorve parte da energia elevando a temperatura, que pode aumentar a quantidade de precipitação (TUCCI, 1997). Desta forma, a cidade de Jataí surgiu às margens da bacia do Jataí que ao longo dos anos vem crescendo ocupando áreas próximas ao córrego do Açude (Sapo), na direção norte, orientação de crescimento nos últimos anos e uma parte na bacia do Capoeira. 
Silva et al., (2002)mostram que as casas muito próximas do leito do córrego do Açude já eram um problema em 2000, quando houve uma enchente inundando várias casas. Em 18 de fevereiro de 2002, ocorreu uma chuva que alagou casas nas proximidades das bacias do Açude e bacia do Jataí, causando muitos transtornos. Na época já se observava a existência de moradores que fixaram suas casas a 10 metros do córrego e a pavimentação na reserva legal do córrego, (SCOPEL, et al., 2002).

Depois de 8 anos da ocorrência do evento de fevereiro de 2002, no dia 2 de março de 2010, de acordo com notícias do Jornal O Globo, Prefeitura de Jataí e o jornal JataíNews, ocorreu mais uma enchente onde o Lago JK transbordou e o nível da água chegou a dois metros de altura em alguns pontos invadindo casas, três bairros foram atingidos; não houve mortos, feridos ou desaparecidos, mas deixou 100 pessoas desabrigadas e encaminhadas a abrigos e casas de parentes.

Desta forma, a cidade de Jataí teve enchente no ano de 2000 e 2010, o que suscitou o interesse em pesquisar os elementos do clima urbano, para entender como esses elementos variam nas duas bacias e por esse motivo não se fez uma pesquisa do clima urbano para a cidade inteira.

A pesquisa teve como objetivo analisar a variação da temperatura do ar máxima e mínima às $9 \mathrm{~h}, 15 \mathrm{~h}$ e $21 \mathrm{~h}$, em escala mensal no ano de 2011 , na bacia do Açude, em área urbana e bacia do Capoeira em área rural de Jataí.

\section{MATERIAL E MÉTODOS}

A área de estudo situa na Microrregião do Sudoeste Goiano, no estado de Goiás, na cidade de Jataí, entre as coordenadas UTM8026000 e $8018000 \mathrm{~N}$ e 430000 e 420000 E, (IBGE 2010), a população é de 88.006 habitantes, sendo que 81.010 residem no espaço urbano. Este estudo foi realizado na bacia do Açude (Sapo), afluente da margem direita do córrego Jataí; a norte da área central direção de expansão da urbanização nos últimos anos, com área de $6,08 \mathrm{Km}^{2}$ e $98 \%$ da área urbanizada, (Figura 1).

Foram instalados thermohigrômetros HT-4000 digitais na bacia do Açude (área urbana) e bacia do Capoeira (área rural) da cidade de Jataí para coletar os dados de temperatura do ar. Os pontosde coleta foram denominados ponto 1 (P1), ponto 2 (P2), ponto 3 (P3), ponto 4 (P4), ponto 5 (P5), ponto 6 (P6), na bacia do Açude (Sapo) e ponto 7 (P7), ponto 8 (P8), ponto 9 (P9) e ponto 10 (P10) na bacia do Capoeira. Foram utilizados dados de temperatura do ar máxima e mínima nos horários de 9, 15 e 21 em 2011, sendo apresentados na escala mensal, (Figura 2), onde foram correlacionados com a hipsometria, exposição das vertentes e uso da terra, com o objetivo de analisar a variação da temperatura do ar, nas duas bacias urbanas e rurais, (Figura 2). 


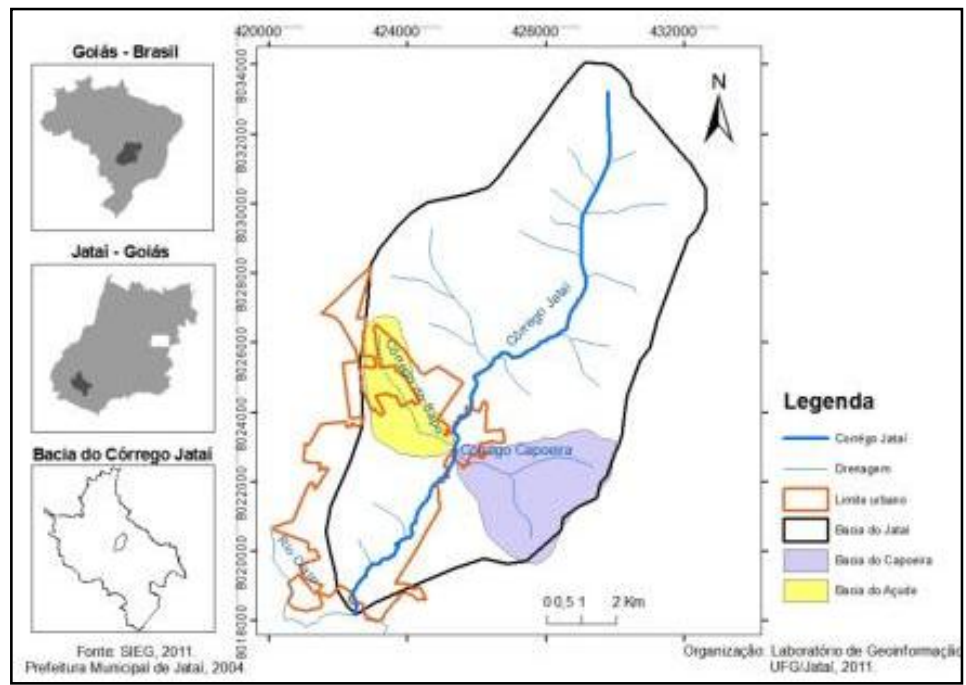

Figura 1- Localização da bacia do Açude e Capoeira em Jataí (GO).

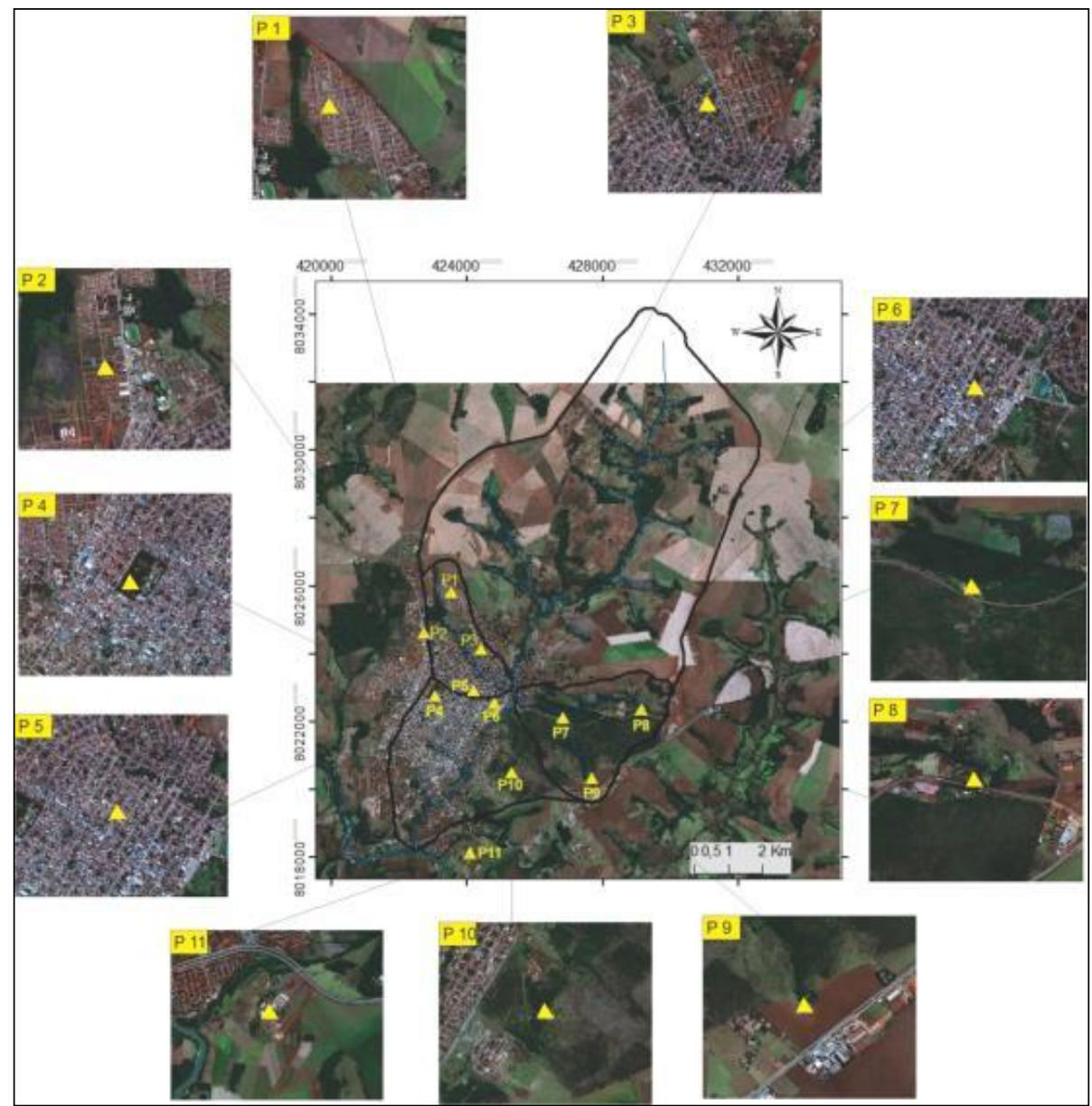

Figura 2- Vista parcial da cidade de Jataí, com os locais de instalação dos equipamentos

\section{RESULTADOS E DISCUSSÃO} de coleta de dados. 
Aspectos da organização do espaço: hipsometria, exposição das vertentes e uso da terra da bacia do Açude (Sapo) e Capoeira

Hipsometria da bacia do Açude (Sapo) e Capoeira

A figura 3 apresenta a hipsometria da bacia do Açude; As altitudes nessa bacia variam entre 650 a $850 \mathrm{~m}$, onde as maiores altitudes encontram-se ao norte e as menores à sudeste, principalmente, na jusante com a bacia do Jataí. As menores altitudes variam entre 650 a $700 \mathrm{~m}$ onde situa o centro da cidade, e as altitudes entre 700 a 750 situam em locais de comércio, onde estão os pontos P6 e P5. Nas altitudes entre 750 a $800 \mathrm{~m}$ leste da bacia, sul - sudoeste situa o ponto (P2), e nas altitudes entre 800 a $850 \mathrm{~m}$ são as maiores. Ao norte do centro, situa o ponto 1 (P1) no setor Mauro Bento, uma das áreas de expansão urbana e próximo ao cultivo de agricultura e da mata do Açude, a maior representação de mata na área urbana. A diferença altimétrica entre o P1 e P6 é de 117 m,que de acordo com Ayoade (1997) em estudos em outras localidades a cada $100 \mathrm{~m}$ de altitude a temperatura diminui a uma taxa de $0,65^{\circ}$. (Figura 3 ). Nesse sentido 0 ponto $\mathrm{P} 1$ na maior altitude durante 0 período analisado apresentou temperaturas menores do que o ponto P5 no centro da cidade nas menores altitudes da bacia, isso mostra que a altitude influenciou para a evidência dos dados apresentados.

Verificou-se que os pontos P5 e P6 estão localizados em cotas altimétricas mais baixas que compreendem o fundo do vale da bacia, apresentaram as maiores temperaturas $\mathrm{P} 5\left(42,4^{\circ} \mathrm{C}\right)$ e $\mathrm{P} 6(41,3)^{\circ}$. Os pontos $\mathrm{P} 1$ e $\mathrm{P} 3$ estão localizados nas maiores cotas altimétricas e apresentou temperaturas entre $P 1\left(43,2^{\circ}\right)$ e $P 3$ $\left(41,0^{\circ} \mathrm{C}\right)$, e o ponto $\mathrm{P} 2$ e P4localizados nas cotas altimétricas entre $750-800 \mathrm{~m}$ registraram as menores temperaturas, ponto P2 $\left(36,6^{\circ} \mathrm{C}\right)$ e $\mathrm{P} 4\left(40,9^{\circ} \mathrm{C}\right)$, (Figura $3)$.

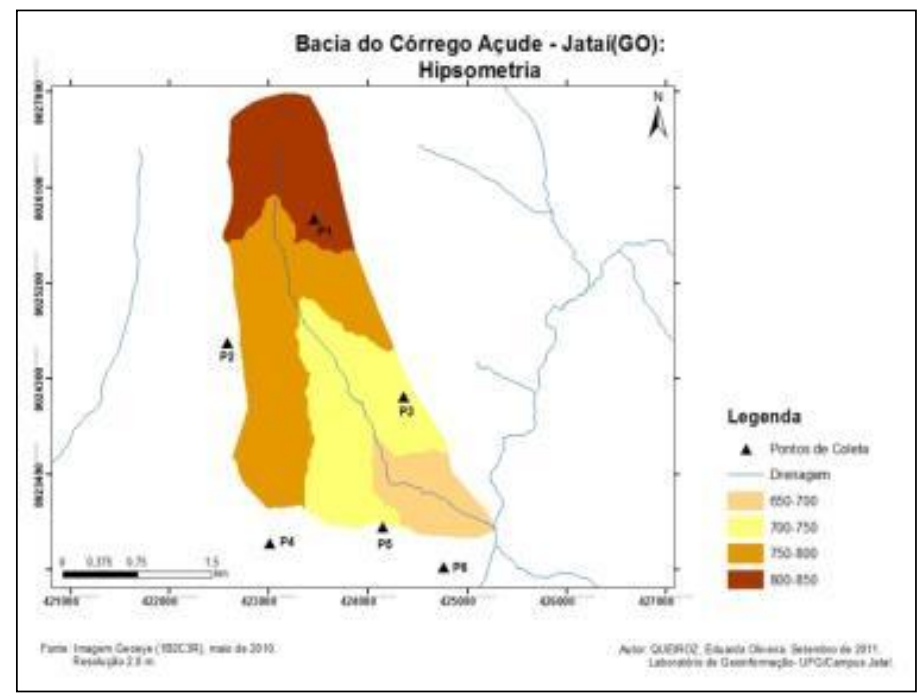

Figura 3- Hipsometria da bacia do Açude - Jataí (GO)

A hipsometria na bacia do Capoeira, tem altitudes que variam entre 650 a 900 $\mathrm{m}$, e as maiores altitudes localizam a nordeste. As altitudes de $650-700$ a oeste, próximo a jusante com o córrego Jataí, são as menores; de $700-750 \mathrm{~m}$ a 
oeste, de 750 a $800 \mathrm{~m}$ estão localizadas a norte, leste e sul da bacia, e altitudes de 850 - $900 \mathrm{~m}$ localizam no leste da bacia.Na bacia do Capoeira do ponto P7 ao $\mathrm{P} 10$, a diferença altimétrica é de $120 \mathrm{~m}$, (Figura 4).

Constatou-se que no ponto P7, localizado na cota altimétrica mais baixa entre 700 - $750 \mathrm{~m}$ da bacia do Capoeira, apresentou as menores temperaturas, oscilando entre $\left(37,9^{\circ} \mathrm{C}\right.$ a $\left.34,6^{\circ} \mathrm{C}\right)$, isso devido encontra-se no vale onde as temperaturas demoram mais a se desfazer. Enquanto o P10 na mesma cota altimétrica registrou temperaturas maiores que o P7 oscilando entre $20,1^{\circ} \mathrm{C}$ e $10,2^{\circ} \mathrm{C}$. O ponto $\mathrm{P} 8$, na maior cota altimétrica registrou as maiores temperaturas $\left(42,2^{\circ} \mathrm{C}\right.$ a $\left.36,1^{\circ} \mathrm{C}\right)$, enquanto o $\mathrm{Pg}$, na mesma cota altimétrica, apresentou temperaturas menores $\left(35,8^{\circ} \mathrm{C}\right.$ a $\left.29^{\circ} \mathrm{C}\right)$.

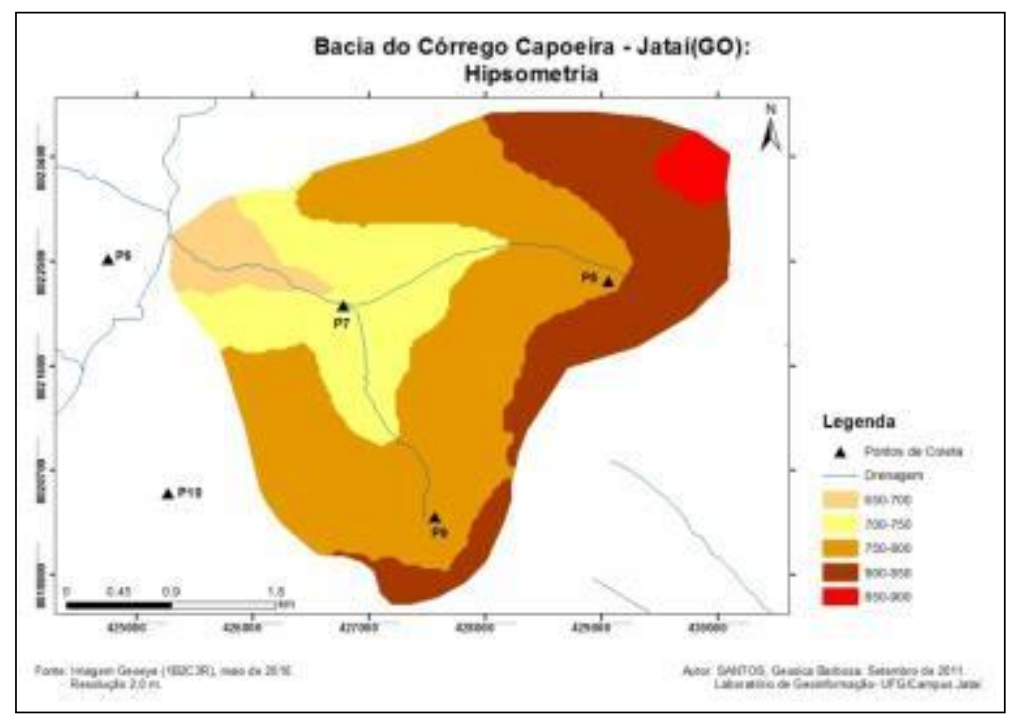

Figura 4 - Hipsometria da bacia do Capoeira - Jataí (GO)

Exposição das vertentes na bacia do Açude e Capoeira

A variação dos elementos climáticos recebe influência direta da exposição do terreno, ou seja, os raios solares incidem mais diretamente nas faces voltadas para o oeste da bacia do Açude (Sapo), onde se localizam os pontos P1 e P3, que transmitem maior quantidade de calor para essa vertente em relação às outras exposições.

Os pontos com as vertentes voltadas para o leste, onde se localizam os pontos P2, P4, P5 e P6, recebem maior energia efetiva no período da manhã, transmitindo menor quantidade de calor em relação às vertentes voltadas para 0 oeste, no entanto cabe ressaltar que os pontos $\mathrm{P} 5\left(42,4^{\circ} \mathrm{C}\right.$ a $\left.35,7^{\circ} \mathrm{C}\right)$ e $\mathrm{P} 6\left(43,0^{\circ} \mathrm{C}\right.$ a $\left.32,8^{\circ} \mathrm{C}\right)$ apresentaram os maiores valores de temperatura. Os pontos $\mathrm{P} 2\left(36,6^{\circ} \mathrm{C}\right.$ a $\left.31,1^{\circ} \mathrm{C}\right)$ e $\mathrm{P} 4\left(37,1\right.$ a $\left.31,1^{\circ} \mathrm{C}\right)$ apresentam as menores temperaturas (Figura 5). 


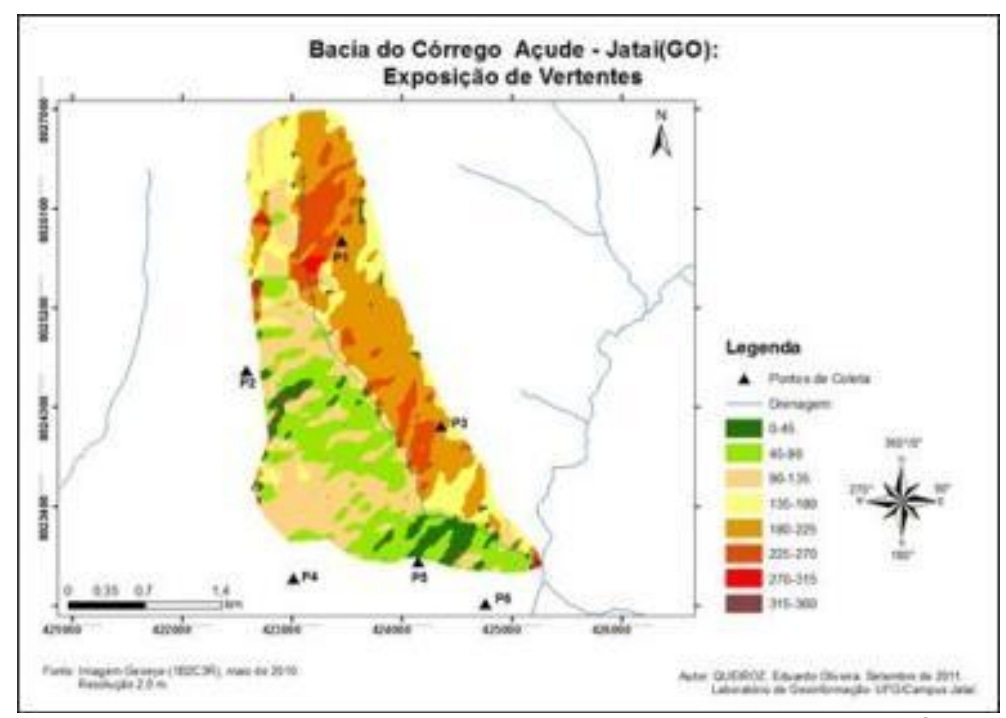

Figura 5- Exposição das vertentes na bacia do Açude -Jataí (GO)

Na bacia do Capoeira, os pontos P8 e P9 posicionados nas faces voltadas para o oeste, recebem maior energia no período da tarde, sendo que, o ponto P8 apresentou as maiores temperaturas que variaram entre $42,2^{\circ} \mathrm{C}$ a $37,2^{\circ} \mathrm{C}$ e no ponto $\mathrm{P9}$ de $35,8^{\circ} \mathrm{C}$ a $29,6^{\circ} \mathrm{C}$. Os pontos $\mathrm{P} 7$ e $\mathrm{P} 10$ recebem a maior energia no período da manhã, e esse lado, portanto, é menos aquecido, o P10 registrou temperaturas entre $39,5^{\circ} \mathrm{C}$ a $32,7^{\circ} \mathrm{C}$ e o $\mathrm{P} 7$ registraram os menores valores de temperatura, $39,0^{\circ} \mathrm{C}$ a $34,6^{\circ} \mathrm{C}$, (Figura 6).

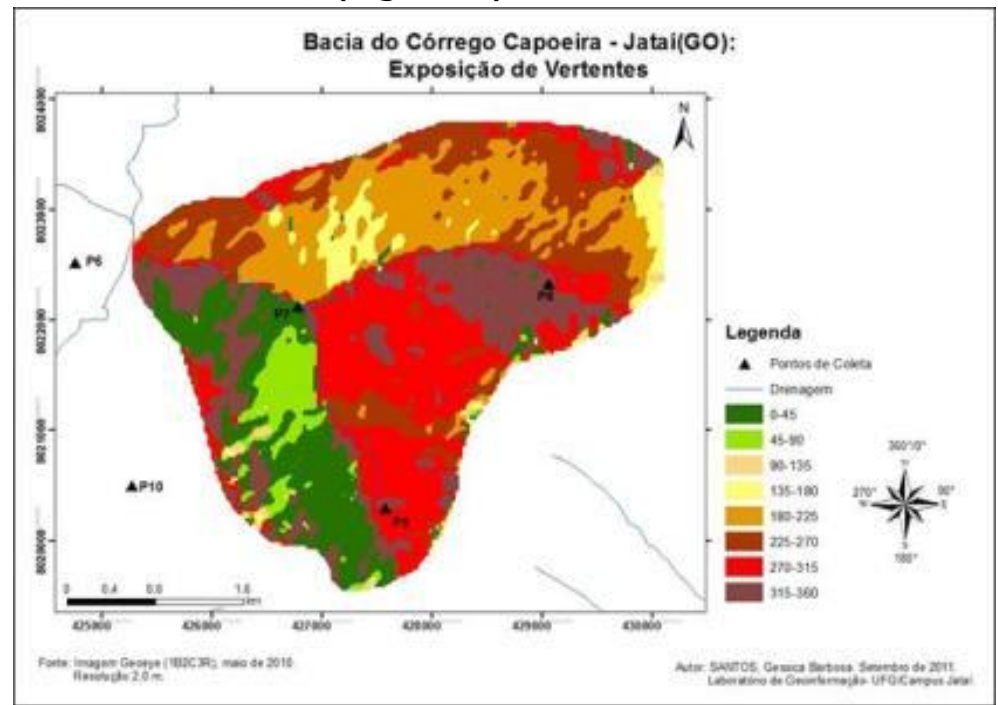

Figura 6- Exposição das vertentes na bacia do Capoeira (GO) Uso da terra na bacia do Açude (Sapo) e Capoeira

O uso da terra para a bacia do Açude (Sapo) e Capoeira foi classificado em quatro classes: vegetação, área construída, área de produção (agrícola)e lago artificial, conforme (Figura 7). 
A área de vegetação na bacia do Açude (Sapo) corresponde a 9,82\% de área ocupada. A vegetação original está localizada na porção norte/noroeste na área da Secretaria Municipal do Meio Ambiente, e em locais do curso do córrego Açude (Sapo). O restante da vegetação é rasteira, e ao longo dos anos foi cedendo lugar à construção de casas e áreas de pastagens como aponta Silva et al., (2002) onde se configurou a partir de meados da década de 90 com o crescimento da cidade na direção norte (Figura 7).

A classe "área construída" tem um percentual na bacia do Açude (Sapo) de $67,29 \%$ de área ocupada. No ponto P1, localizado ao norte da cidade em direção à expansão urbana, apresenta pavimentação e pouca arborização. $\mathrm{O}$ ponto $\mathrm{P} 2$, no ano de 2011 vem apresentando muitas mudanças com a construção do shopping, muitas ruas passaram por pavimentação, novas edificações; o P4 está em local que apresenta arborização, gramíneas e poucas edificações. O ponto P3 apresenta área construída com pavimentação, fluxo de veículos e pessoas e pouca arborização. $\mathrm{Na}$ área central da cidade, localizam-se os pontos P5 $(42,4 \mathrm{a}$ $\left.35,7^{\circ} \mathrm{C}\right)$ e $\mathrm{P} 6\left(43,0\right.$ a $\left.32,8^{\circ} \mathrm{C}\right)$ onde ocorre maior impermeabilização do solo pela presença de materiais construtivos, ruas pavimentadas, prédios comerciais, maior fluxo de veículos e pessoas. Esses locais apresentaram os maiores valores de temperaturas. (Figura 7).

A área que ocorre a presença de monoculturas de milho e soja nessa bacia aparece principalmente ao norte, ao longo do curso do córrego do Açude (Sapo), com presença de chácaras com atividade de hortas, com criação de animais e o plantio de subsistência, (Figura 7).

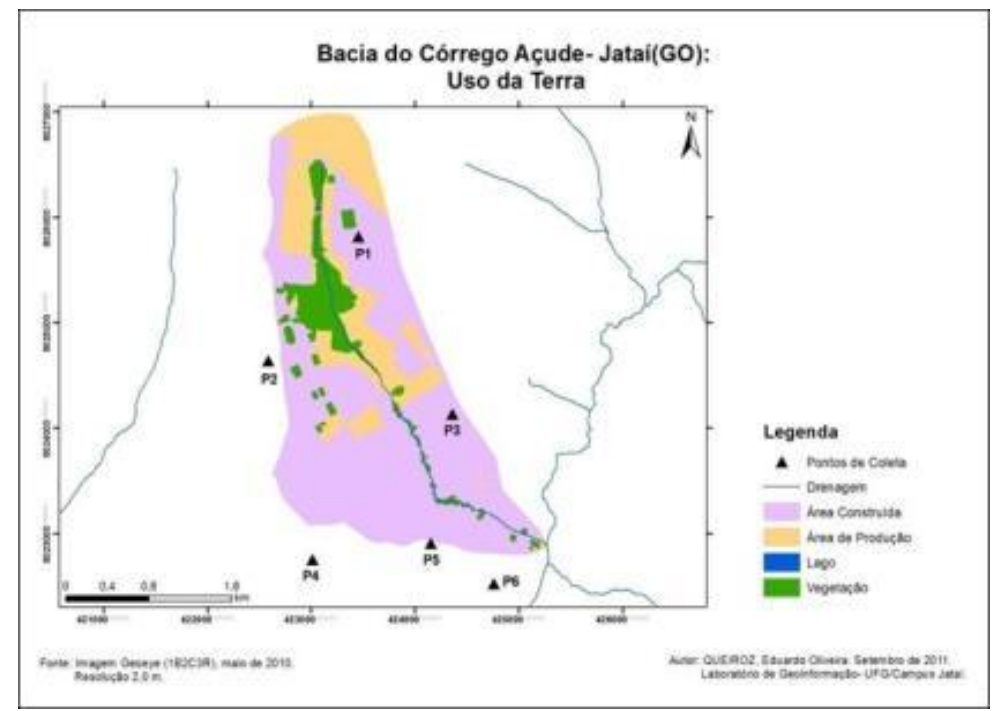

Figura 7- Uso da terra na bacia do Açude - Jataí (GO)

Na bacia do Capoeira, a área de vegetação corresponde a $62,4 \%$ da bacia, em sua maioria no ( $41^{\circ}$ BTMz- Batalhão de Infantaria Motorizado) preservada e no fundo dos vales, próximo ao curso do córrego do Rego e Capoeira, a vegetação é rasteira e original, local onde situa o ponto 7. Nesse local, apresentam temperaturas máximas amenas oscilando entre $38,4^{\circ} \mathrm{C}$ a $34,6^{\circ} \mathrm{C}$. No ponto $\mathrm{P} 10$, localizado no Clube dos Sargentos, apresenta pavimentação, construções para lazer (Figura 8). 
A área construída apresenta as maiores densidades em bairros próximos à bacia do Capoeira com a bacia do Jataí em terrenos doados pelo poder público, que estão a leste da cidade e que não é difícil de ver pessoas ocupando áreas consideradas de risco, que já foram palco de duas enchentes em 2002 e depois em 2010. Ao sul da bacia, encontram-se área com construções de casas, ruas abertas com chácaras de lazer, próximas a BR - 060.

A classe área de produção localizada ao norte, leste, sul e oeste sendo que nessas áreas destacam-se a produção de hortaliças em várias áreas do Ponto 8, pois, nas proximidades além das hortaliças existem gramíneas e a Avenida Alameda das Primaveras, esse ponto apresentou temperaturas que variou entre $42,2^{\circ} \mathrm{C}$ a $35,8^{\circ} \mathrm{C}$. Nessa bacia, também, se encontra a produção de grão como milho e soja. O Ponto 9 localizado em área rural, tem nas proximidades, uma nascente e vegetação, é o segundo ponto onde ocorrem as menores temperaturas oscilando na máximas entre $35,8^{\circ} \mathrm{C}$ a $29,6^{\circ} \mathrm{C}$, principalmente, nos meses que correspondem ao período chuvoso (Figura 8).

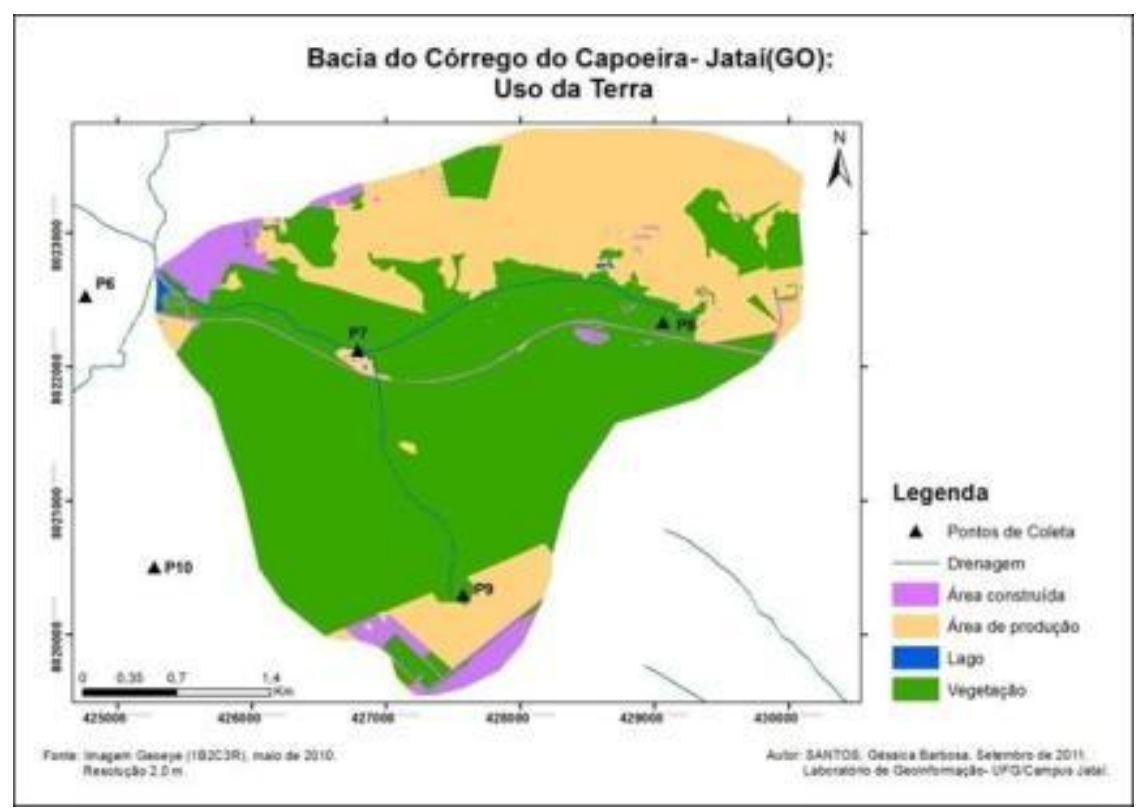

Figura 8 - Uso da terra na bacia do Capoeira. 
É importante conhecer o sítio urbano nos aspectos da hipsometria, exposição das vertentes e uso da terra, para entender como ocorrem às variações da temperatura do ar. O ponto P5 localizado nas menores altitudes no vale, no centro da cidade apresentou as menores temperaturas, mesmo esse ponto tendo maior exposição de leste no período da manhã e no uso da terra com maior intensidade de área construída com ruas pavimentadas, intenso fluxo de veículos e pessoas e pouca arborização. Assim na bacia do Açude as diferenças de uso da terra foram importantes para influenciar nas diferenças de temperaturas, e a hipsometria dos pontos mais altos, como o P1 se mostrou como elemento atenuador das temperaturas, pois apesar de ter maior exposição de oeste, com maior radiação solar no período da tarde não foi o ponto com as maiores temperaturas da bacia.

$\mathrm{Na}$ bacia do Capoeira o ponto P7 (650 - $700 \mathrm{~m})$, localizado nas menores altitudes no vale registrou os menores valores de temperatura e exposição de leste com maior radiação solar no período da manhã. Ainda no uso da terra possui grande quantidade de vegetação de cerrado original nas proximidades e gramínea fatores estes que fizeram que ocorresse diminuição nas temperaturas. O ponto P8 $(800-850 \mathrm{~m})$ nas mais elevadas altitudes da bacia e a exposição de oeste recebeu maior radiação solar no período da tarde, que é elemento influenciador nesse ponto para os maiores valores de temperatura do ar e no uso da terra com vegetação rasteira e solo exposto devido à movimentação do solo para o plantio de hortaliças também contribuiu para os valores mencionados, que faz com que tenha maior absorção e reflexão tornando as temperaturas com valores menores rapidamente com o adentrar da noite.

Variação térmica nas bacias do Açude (Sapo) e Capoeira em Jataí/GO, as 9, 15 e $21 h$

Às $9 \mathrm{~h}$, as temperaturas do ar máximas mensais da bacia do Açude oscilaram entre $40,0^{\circ} \mathrm{C}$ a $23,0^{\circ} \mathrm{C}$, o P5 foi à localidade de maior valor $\left(40,0^{\circ} \mathrm{C}\right)$, nos meses de maio a agosto, localizado no centro da cidade, onde ocorre maior fluxo de veículos, maior concentração de áreas construídas que favorece os valores de temperatura registrados, (Figura, $9 \mathrm{~A}$ e 10 ) e as menores temperaturas no P4 $\left(23,0^{\circ} \mathrm{C}\right)$, pois é uma área com maior arborização, gramíneas e edificações esparsas.

Na bacia do Capoeira, as temperaturas do ar máximas mensais às $9 \mathrm{~h}$, variaram entre $38,1^{\circ} \mathrm{C}$ a $26,6^{\circ} \mathrm{C}$, no ponto P8 ocorreram os maiores valores para os meses de janeiro a agosto e outubro, novembro localizado em local com maior exposição da vertente para o oeste que mesmo no período da manhã já começa a se aquecer, mas é no período da tarde que apresenta as maiores temperaturas. A vegetação do local é rasteira (gramíneas) e área de produção de hortaliças com a falta de arborização influenciam para os maiores valores de temperatura. Os menores valores das temperaturas máximas ocorreram no P9, em localidade com maior quantidade de vegetação, (Figura 9 B e 10). O ponto 
P10 apresentou o maior valor registrado em todo período analisado de $42,1^{\circ} \mathrm{C}$, no mês de setembro, período de estiagem quando a vegetação perde as folhas; e ainda, esse local passou por transformações com a pavimentação asfáltica de via de acesso ao local.

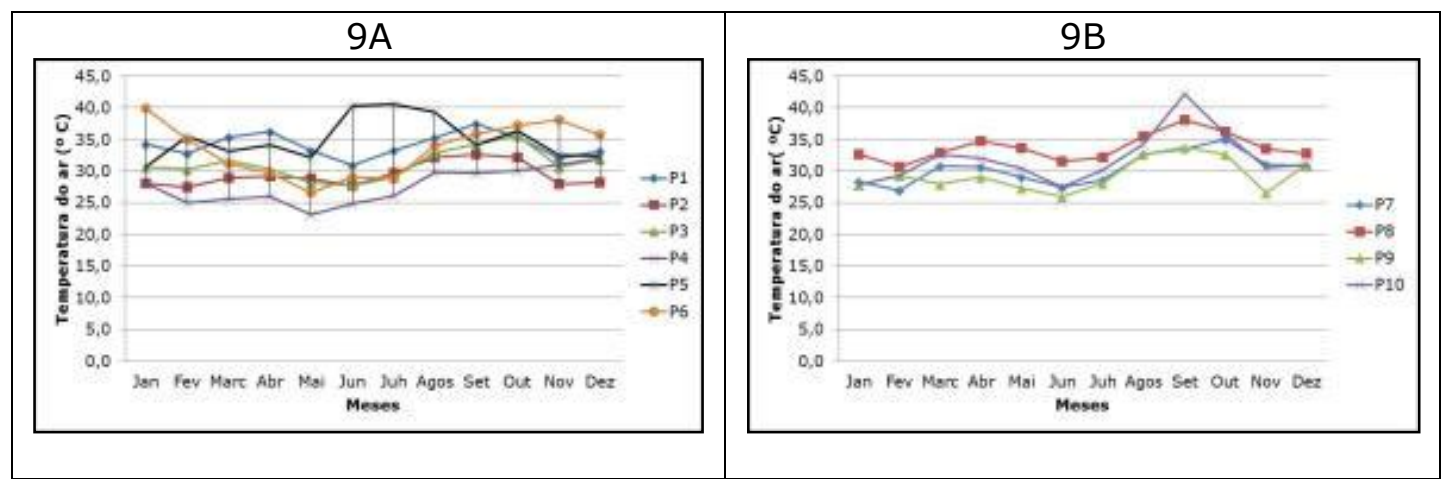

Figura 9 - Variação da temperatura do ar máxima mensal, na bacia do Açudee Capoeiraàs $9 \mathrm{~h}$.

Às $9 \mathrm{~h}$, as temperaturas do ar mínimas na bacia do Açude oscilaram entre $22,7^{\circ} \mathrm{C}$ a $8,1^{\circ} \mathrm{C}$, sendo que o maior valor ocorreu no ponto P5, nos meses de abril, maio e setembro, localizado no centro da cidade, mas o ponto com as temperaturas maiores nos de janeiro a março, maio, junho e setembro a dezembro; no P6, apresenta maior quantidade de área construída, com edificações, fluxo de pessoas e veículos. Os menores valores da mínima ocorreram no ponto P4 nos meses de janeiro a dezembro, devido maior quantidade de vegetação (gramíneas e arborização) e edificações esparsas, (Figuras 10 A e 11).

$\mathrm{Na}$ bacia do Capoeira, as temperaturas do ar mínimas mensais às 9 horas variaram entre $21,8^{\circ} \mathrm{C}$ e $8,1^{\circ} \mathrm{C}$, o maior valor ocorreu no P8, nos meses de abril, maio, agosto, setembro, novembro localizado em área de hortaliça com gramíneas, a exposição é de oeste que recebe maior radiação solar no período da tarde.Os menores valores no P9 devido a maior quantidade de vegetação (arborização e gramíneas) e na área de produção (plantações de soja e milho) e poucas edificações. Encontra-se nas maiores altitudes $(773 \mathrm{~m})$ da bacia e tem maior exposição dessa vertente ao sol no período da tarde, (Figura 10 B e 11). No horário das $15 \mathrm{~h}$, as temperaturas do ar máximas mensais na bacia do Açude oscilaram entre 40,0 a $23,0^{\circ} \mathrm{C}$, o P6 registrou o maior valor e o menor no P4, no entanto no tempo de análise, o ponto P5 registrou os maiores valores de temperatura nos meses de abril a setembro, que estão relacionados ao uso da terra, que pela localização no centro da cidade, com maior concentração de áreas construídas, localiza-se no vale (Figura $12 \mathrm{~A}$ ). $\mathrm{O}$ ponto $\mathrm{P} 4$, que registrou os menores valores de temperatura nos meses de janeiro a outubro, tem maior quantidade de vegetação, gramíneas, arborização e construções esparsas, com maior exposição da vertente de leste que recebe maior absorção de calor no período da manhã que apresenta temperaturas menores, (Figura $12 \mathrm{~A}$ e 14). 

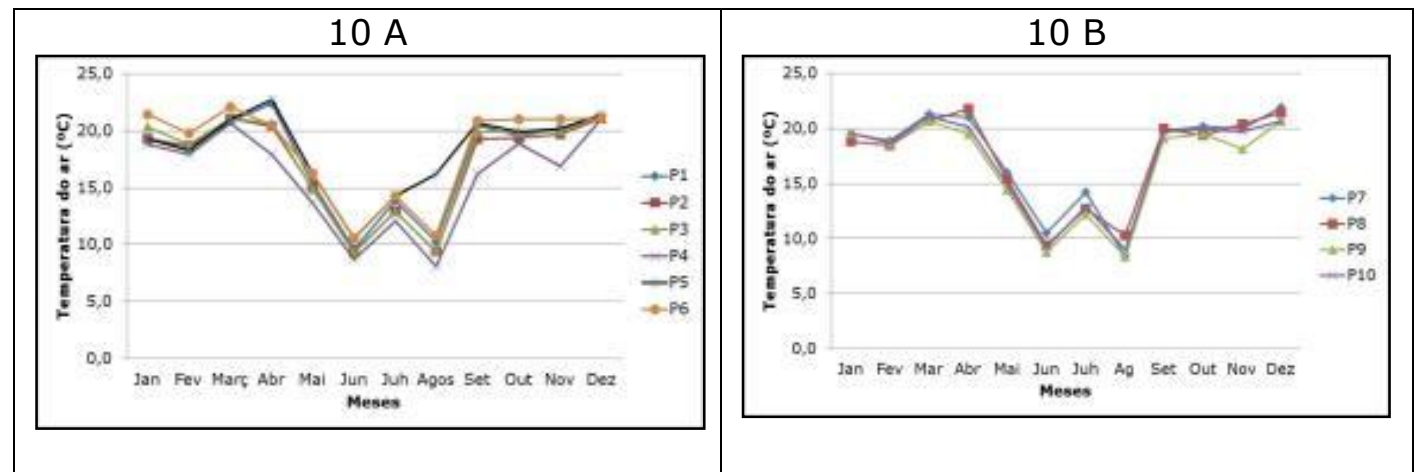

Figura 10. Variação da temperatura do ar mínima mensal, na bacia do Açude (Sapo), (A) e Capoeira, (B) as 9h.

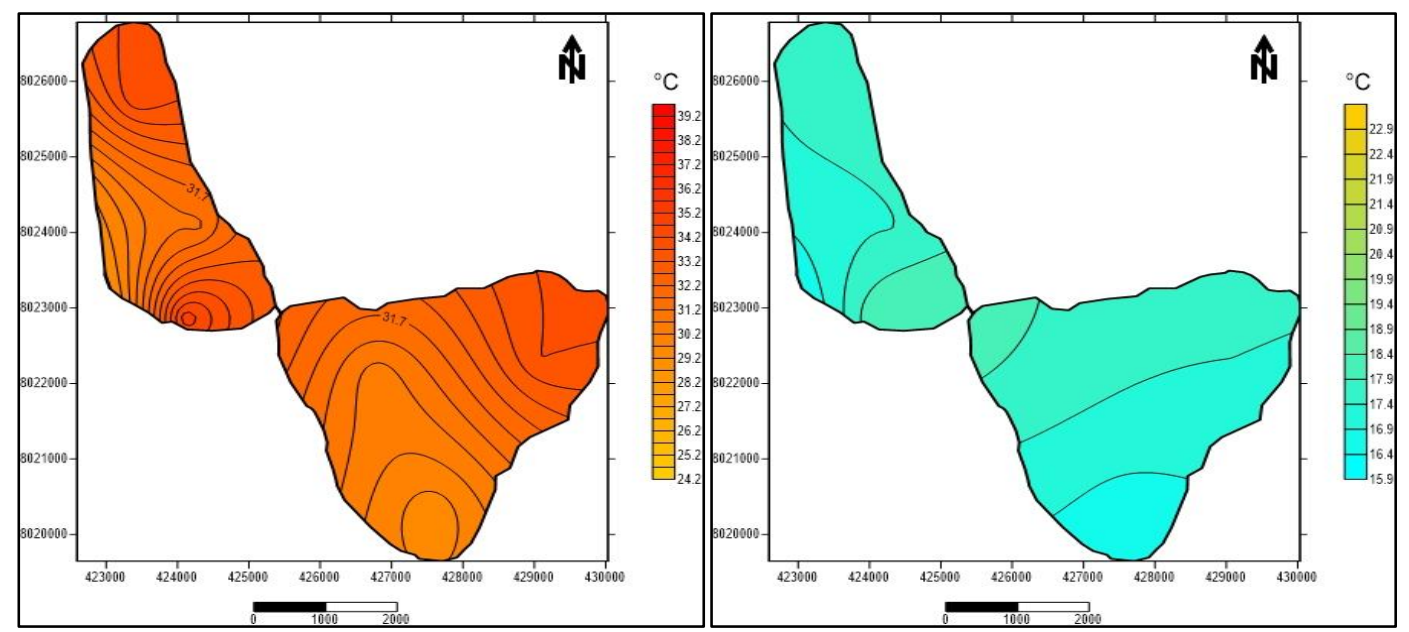

Figura 11 - Variação da temperatura do ar média máxima e mínima em 2011, na bacia do Açude e Capoeira às 9h.

Na bacia do Capoeira, as temperaturas do ar máximas mensais às 15 horas variaram entre 29,6 a $42,2^{\circ} \mathrm{C}$, o maior valor ocorreu no $\mathrm{P} 8$, nos meses de janeiro a julho e setembro a dezembro, que estão relacionados a exposição da vertente para o oeste com maior absorção de calor no período da tarde e os menores valores no P9, se relacionam com a maior quantidade de vegetação existente no local. Esse ponto tem maior exposição de sua vertente no período da tarde de oeste, mas a vegetação ameniza os efeitos da absorção de calor, contribuindo para menores temperaturas.O ponto P10 no mês de agosto registrou entre os pontos o maior valor $\left(46,0^{\circ} \mathrm{C}\right)$ de temperatura entre os meses analisados; esse fato deve pelos efeitos da estiagem que faz com que a vegetação perca suas folhas e as mudanças no local de pavimentação asfáltica de via de acesso contribuíram para maior valor de temperatura, (Figura $12 \mathrm{~B}$ e $14 \mathrm{~B})$. 


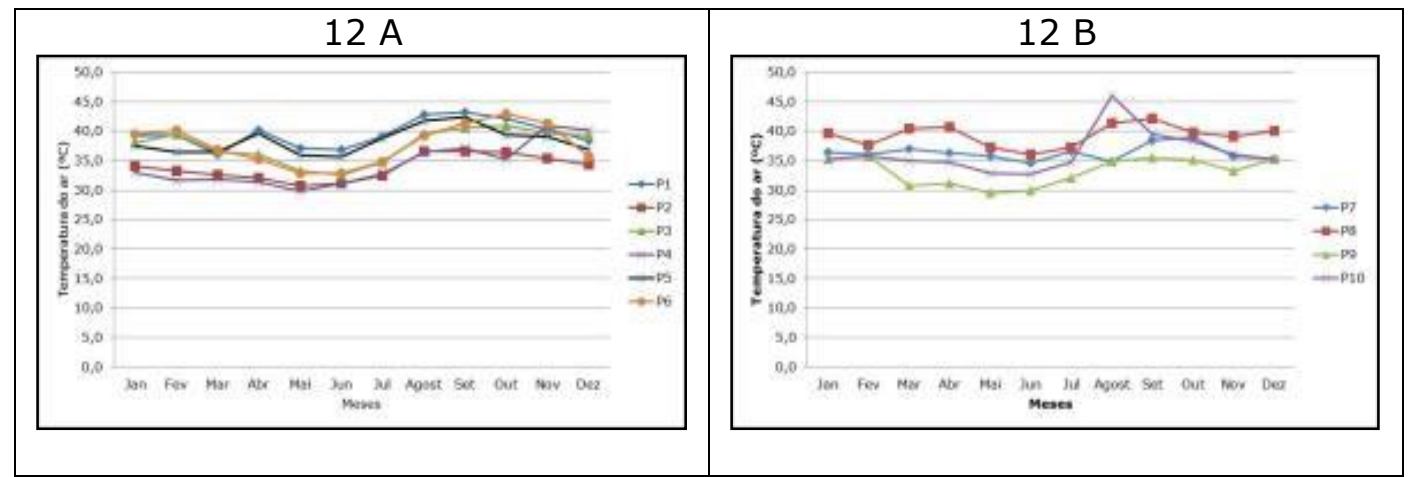

Figura 12. Variação da temperatura do ar máxima, mensal na bacia do Açude (Sapo) e Capoeira, as 15h.

As temperaturas do ar mínimas às $15 \mathrm{~h}$ na bacia do Açude oscilaram entre $30,9^{\circ} \mathrm{C}$ a $14,1^{\circ} \mathrm{C}$, o maior valor ocorreu no P1 e P5 no mês de junho, julho e agosto, setembro e no P6 nos meses de janeiro a maio e outubro e novembro, sendo, portanto, o ponto com temperaturas maiores na maioria dos meses, que ocorreram devido a sua localização no centro da cidade em rua paralela ao centro comercial no vale, que dificulta a dispersão de calor. E os menores valores da mínima no P4, ocorreram devido a maior quantidade de vegetação, poucas edificações com construções esparsas, (13 A e 14).

$\mathrm{Na}$ bacia do Capoeira (rural) as temperaturas do ar mínimas mensais as 15 horas oscilaram entre $28,7^{\circ} \mathrm{C}$ a $13,4^{\circ} \mathrm{C}$, os maiores valores da temperatura mínima ocorreram no P10 nos meses de janeiro, março, abril e agosto, outubro, novembro e dezembro. A localidade de maiores valores da mínima, isso devido a exposição da vertente ser de oeste que recebe maior radiação solar no período da tarde, as mudanças ocorridas no local, com a pavimentação da via de acesso. Os menores valores da mínima que ocorreram no P8, justificam-se por estar nas maiores altitudes da bacia e ser uma hortaliça que é faz a irrigação constante, (Figuras 13 B e 14).

As temperaturas do ar máximas mensais às $21 \mathrm{~h}$, na bacia do Açude, oscilaram entre $30^{\circ} \mathrm{C}$ a $22,5^{\circ} \mathrm{C}$, os maiores valores ocorreram no $\mathrm{P} 2$, nos meses de abril a setembro, devido a estiagem nesses meses, a vegetação perde suas folhas e a construção do Shopping com maior quantidade de área construída, ruas pavimentadas, contribuíram para uma maior absorção de calor nesses meses. 0 menor valor que correu no P4, nos meses de janeiro a junho e setembro, novembro e dezembro, devido maior quantidade de vegetação, maior exposição da vertente de leste que recebe maior radiação solar no período da manhã, (Figura 15 A e17). 


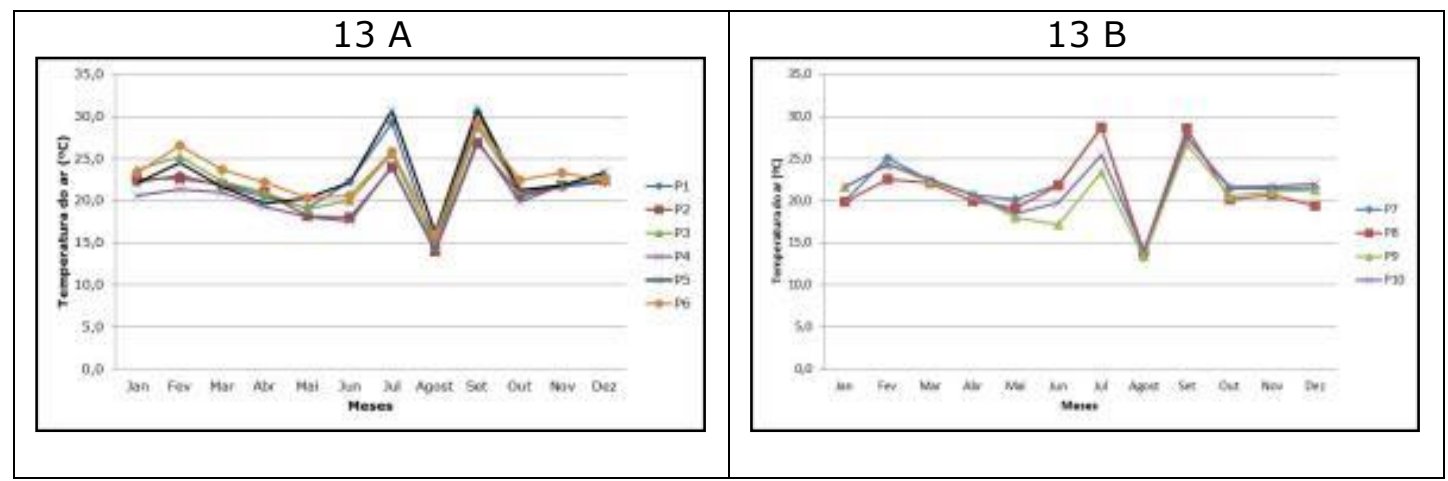

Figura 13. Variação da temperatura do ar mínima, mensal na bacia do Açude (Sapo) e Capoeiras às15h.

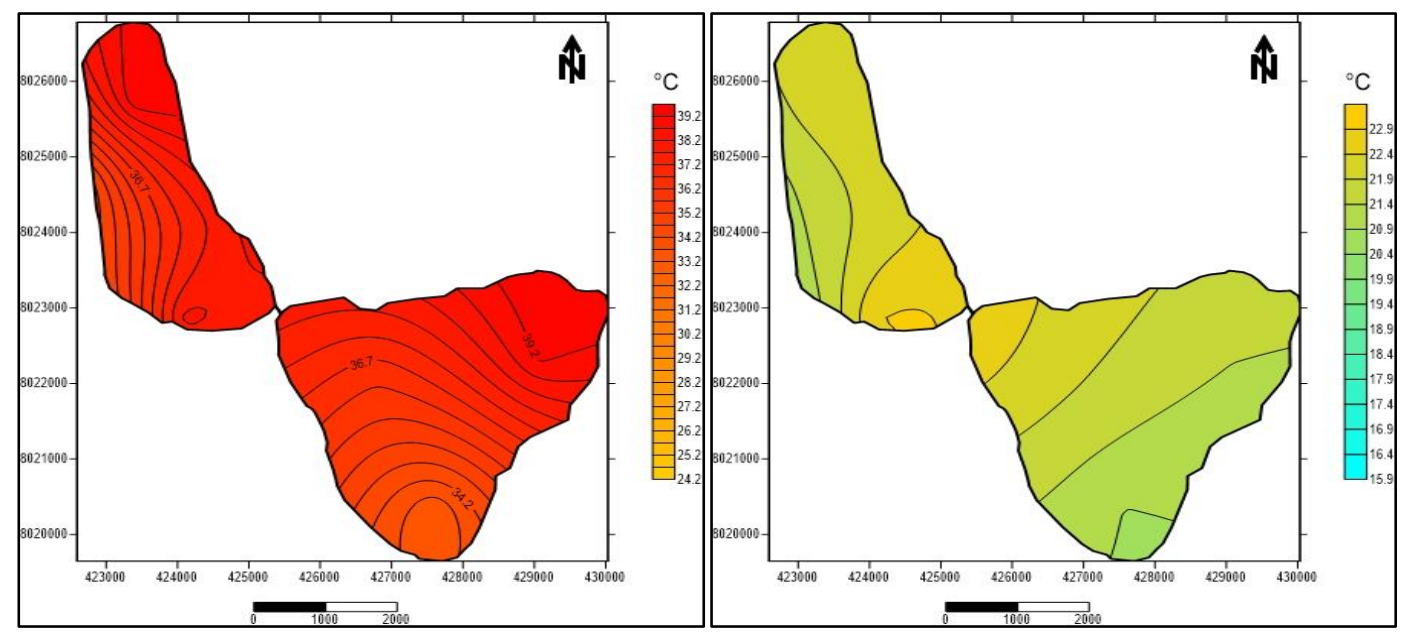

Figura 14 - Variação da temperatura do ar média máxima e mínima em 2011, na bacia do Açude e Capoeira às 15h.

Na bacia do Capoeira as temperaturas do ar máximas mensais absolutas, as $21 \mathrm{~h}$, variaram entre $28,3^{\circ} \mathrm{C}$ a $21,1^{\circ} \mathrm{C}$, os maiores valores ocorreram no $\mathrm{P9}$, nos meses de janeiro, maio, junho, julho, novembro e dezembro, devido essa vertente ter exposição de oeste e receber maior radiação solar no período da tarde e mantém o calor até a noite. Os menores valores foram no P8, nos meses de janeiro a junho e agosto a dezembro, devido esse local ser destinado a hortaliças que recebe irrigação ao entardecer, amenizando as temperaturas nesse horário, (Figura 15 B e 17).

As temperaturas do ar mínimas absolutas mensais na bacia do Açude, às 21 horas, oscilaram entre $22,9^{\circ} \mathrm{C}$ a $11,2^{\circ} \mathrm{C}$, o maior valor ocorreu no $\mathrm{P} 6$, nos meses de janeiro; a maior, agosto e outubro a dezembro, devido localização em rua paralela ao centro comercial com maior quantidade de área construída, pavimentação e pouca arborização, intenso fluxo de veículos e pessoas, no fundo do vale, dificultando o calor desfazer ao material construtivo. Os menores valores ocorreram no P4, nos meses de janeiro a dezembro, devido maior 
quantidade de vegetação (arborização e gramíneas) e poucas edificações, (Figura 16 A e 17).
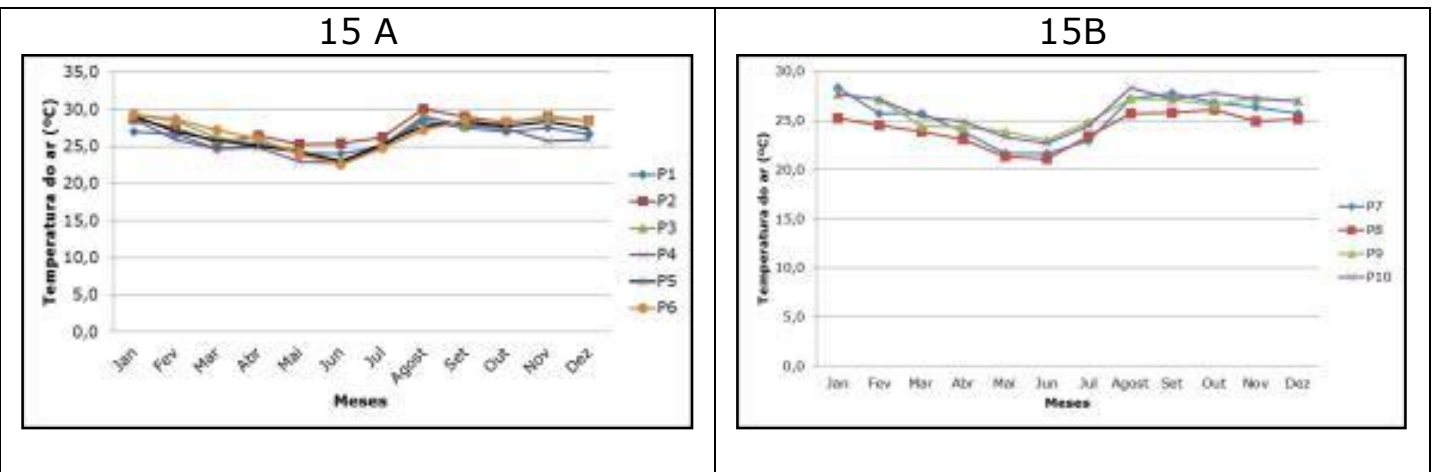

Figura 15. Variação da temperatura do ar máxima, mensal na bacia do Açude (Sapo) e Capoeira às21h.

Na bacia do Capoeira, as temperaturas do ar mínimas absolutas mensais, às 21 horas, oscilaram entre $21,6^{\circ} \mathrm{C}$ a $9,7^{\circ} \mathrm{C}$, os maiores valores ocorreram no $\mathrm{P} 10$, nos mês de janeiro a abril, agosto e outubro a novembro, devido a pavimentação da via de acesso, a exposição da vertente ser de oeste com maior radiação no período da tarde. Os menores valores ocorreram no P8, nos meses de janeiro a junho, agosto e outubro a dezembro, devido à irrigação das hortaliças, que ocorrem no final da tarde e que atenuam a temperatura nesse horário, (Figura 16 B e 17).
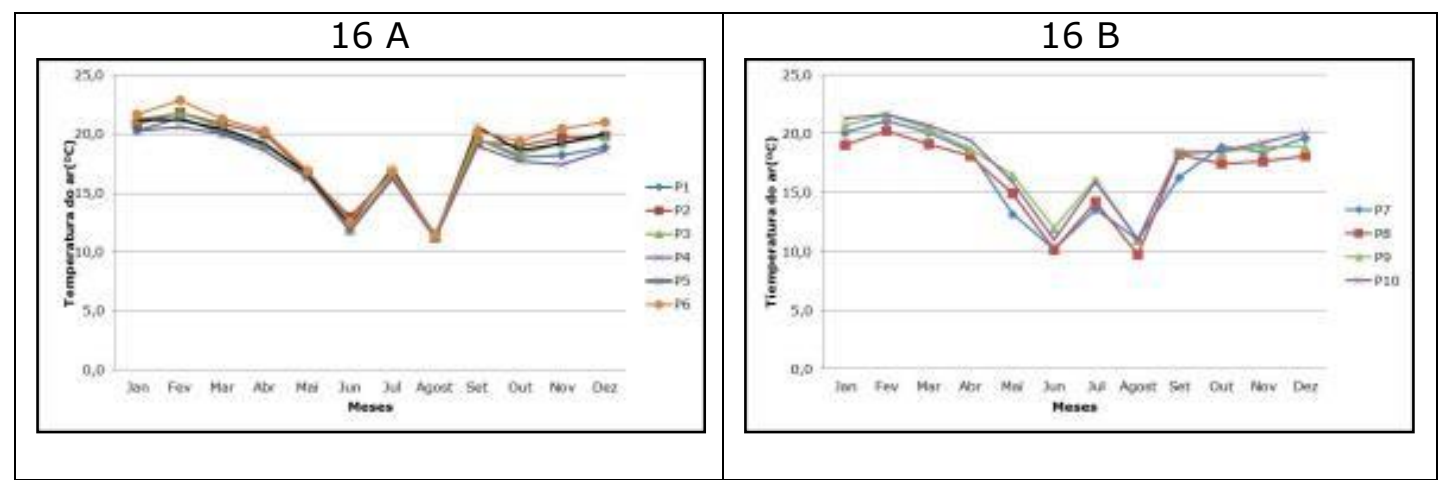

Figura 16. Variação da temperatura do ar mínima, mensal na bacia do Açude (Sapo) e Capoeiras às $21 \mathrm{~h}$. 


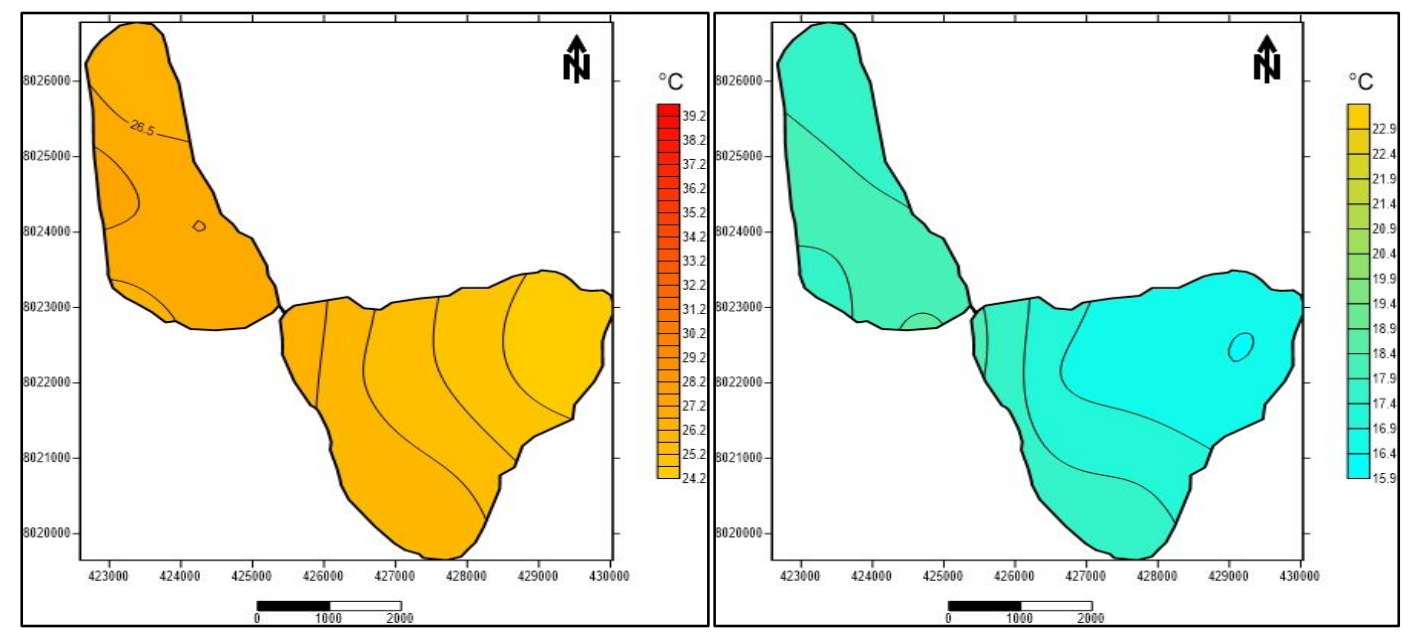

Figura 17 - Variação da temperatura do ar média máxima e mínima em 2011, na bacia do Açude e Capoeira às 21h.

\section{CONCLUSÕES}

Os resultados da pesquisa demonstraram que a variação da temperatura do ar ocorreu devido à influência da hipsometria, exposição das vertentes e o uso da terra.

$\mathrm{Na}$ bacia do Açude os pontos localizados em altitudes com intervalos entre 700 a 850 que corresponde aos pontos P1， P2, P3, P4nas maiores altitudes apresentaram valores menores de temperatura em relação aos pontos P5 e P6 (700 - 650) que estão nas menores altitudes no vale, registraram os maiores valores de temperatura do ar.

Em relação à exposição das vertentes da bacia do Açude verificou-se que os pontos $\mathrm{P} 1$ e $\mathrm{P} 3$ que têm maior exposição de oeste no período da tarde não foram os pontos com as maiores temperaturas, o que prevaleceu foi o efeito da altitude e os pontos P2 e P4 com maior exposição de leste no período da manhã e com maior quantidade de vegetação apresentaram temperaturas menores, nos pontos P5 e P6 com exposição também de leste no período da manhã apresentaram as maiores temperaturas em função do uso da terra, que encontram-se em área construída com maior quantidade de pavimentação, fluxo de pessoas, veículos, epouca arborização.

Verificou-se que os locais com uso da terra com maior área de pavimentação, área construída, pouca vegetação e maior fluxo de veículos e de pessoas no centro da cidade nos pontos P5 e P6, apresentaram as maiores temperaturas, devido maior absorção de calor e sua localização no vale que demora mais para o calor se desfazer.

Na bacia do Capoeira os pontos P8 e P9 estão nas maiores altitudes no entanto as menores temperaturas ocorreram no $\mathrm{P} 9$ em relação ao $\mathrm{P} 8$. $\mathrm{O}$ ponto $\mathrm{P} 7$ nas menores altitudes apresentou os menores valores de temperatura e o ponto P10 com altitude de $773 \mathrm{~m}$ não foi o ponto com as menores temperaturas da bacia. 
Com relação à exposição das vertentes verificou-se que o ponto P8 com exposição de oeste que recebe maior radiação solar no período da tarde foi o ponto mais quente da bacia. $O$ ponto $P 9$ também tem exposição de oeste registrou temperaturas menores do que o $\mathrm{P} 8$, pois o que prevalece é a maior quantidade de vegetação que possui e os pontos P7 e P10 com exposição de leste recebe maior radiação pela manhã teve as menores temperaturas.

Constatou-se que no uso da terra na bacia do Capoeira o ponto P8, com a presença de vegetação rasteira e solo exposto registrou os maiores valores de temperaturas. $\mathrm{O}$ ponto $\mathrm{P} 9 \mathrm{com}$ maior quantidade de vegetação teve temperaturas menores em relação ao P8. Os pontos P10 e P7 registraram valores de temperaturas menores devido a vegetação e gramíneas.

As temperaturas máximas às $9 \mathrm{~h}$ na bacia do Açude foram maiores no ponto $\mathrm{P} 5$ $\left(40,0^{\circ} \mathrm{C}\right)$ e o ponto $\mathrm{P} 4\left(23,0^{\circ} \mathrm{C}\right)$ ocorreram as menores temperaturas e às $15 \mathrm{~h} \mathrm{o}$ ponto $\mathrm{P} 5$ teve $42,4^{\circ} \mathrm{C}$ com os maiores valores de temperatura e os menores valores de temperaturas mínimas no $\mathrm{P} 4\left(14,1^{\circ} \mathrm{C}\right)$.

Às $21 \mathrm{~h}$ na bacia do Açude as temperaturas máximas foram maiores no P2 $\left(30^{\circ} \mathrm{C}\right)$ e os menores valores da mínima no P4 $\left(11,2^{\circ} \mathrm{C}\right)$.

$\mathrm{Na}$ bacia do Capoeira as temperaturas do ar máximas às $9 \mathrm{~h}$ foram maiores no $\mathrm{P} 8$ $\left(38,1^{\circ} \mathrm{C}\right)$ e os menores valores da temperatura do ar mínima no $\mathrm{Pg}\left(8,1^{\circ} \mathrm{C}\right)$; às $15 \mathrm{~h}$ foram maiores no $\mathrm{P} 8\left(42,2^{\circ} \mathrm{C}\right)$ e os menores valores da mínima no P8 $\left(13,4^{\circ} \mathrm{C}\right)$ e às $21 \mathrm{~h}$ as temperaturas máximas foram maiores no $\mathrm{P9}\left(28,3^{\circ} \mathrm{C}\right)$ e os menores valores da mínima ocorreram no P8 $\left(21,8^{\circ} \mathrm{C}\right)$.

Verificou-se, portanto que os maiores valores de temperatura do ar máxima ocorreram na bacia do Açude com uso urbano, nos pontos com maior concentração de área construída e os menores valores nos locais com maior quantidade de vegetação e com uso rural.

\section{REFERÊNCIAS}

ANDRADE, A. de. R.; ROSEGHINI, W. F. F.; MENDONÇA, F. de. A. Análise do campo térmico da cidade de Irati (PR): primeiros experimentos para a definição do clima urbano. Revista Brasileira de Climatologia. Presidente Prudente, v. 6, p. 57-77. 2010. Disponível em: <http://ojs.c3sl.ufpr.br/ojs2/index.php/revistaabclima/article/viewFile/25587/17 155>. Acesso em 13 nov. 2011.

AYOADE, J. O. O clima e o homem. In: Introdução a climatologia para os trópicos. Rio de Janeiro: Bertrand Brasil, 1997. p. 286 - 318.

FREITAS V. V. de. et al.. Temperaturas, matutinas e vespertinas de inverno na cidade de Jataí em 2004. In: REUNIÃO ANUAL DA SBPC. 2004. Fortaleza (CE). Anais eletrônicos... $\quad$ Fortaleza: $2004 . \quad$ Disponível em:<http://www.sbpcnet.org.br/livro/57ra/programas/senior/RESUMOS/resumo 399.html>. Acesso em: 20 nov. 2011.

IBGE. Censo Demográfico de 2010. Resultados preliminares. Rio de Janeiro. 2010.http://www.ibge.gov.br. Acesso em: $10 \mathrm{dez}$. 2011. 
LIMA, A. P. AMORIM, M. T. C. C. T. Diagnóstico da formação do clima urbano em Rosana/SP. Disponível em: <http://www.geo.ufv.br/simposio/simposio/trabalhos/trabalhos_completos/eixo 8/001.pdf.> Acesso em: 10 dez. 2011.

LIMA, V. AMORIM, M. C. C. T. A utilização de informações de temperatura da superfície, do NDVI e de temperatura do ar na análise de qualidade ambiental urbana. In: SIMPÓSIO BRASILEIRO DE SENSORIAMENTO REMOTO, 15, 2011, Curitiba. Anais eletrônicos... Curitiba: 2011. Disponível em: http://marte.dpi.inpe.br/col/dpi.inpe.br/marte/2011/07.14.19.00/doc/p1165.pdf . Acesso em: 08 ago. 2011.p. 1-8.

MONTEIRO, C. A. de. Adentrar a cidade para tomar-lhe a temperatura. Revista Geosul, Florianópolis-SC: Editora da UFSC, 1990. n. 9, ano v, primeiro semestre, p. 61-80, 1990.

MONTEIRO, C. A. de. F. Teoria e clima urbano. 1976.181 f. Tese. (Apresentada ao concurso de livre- docência junto ao Departamento de Geografia) - Faculdade de Filosofia, Letras e Ciências Humanas da Universidade de São Paulo, São Paulo, 1976.

PEREIRA, P. V. dos. S.; BRANDÃO, A. M. P. M. Prováveis correlações entre urbanização e derivações do clima local - Estudo de caso do bairro da Penha/RJ. In: SIMPOSIO BRASILEIRO DE SENSORIAMENTO REMOTO, 14, 2009, Natal. Anais eletrônicos... Natal: UFRJ, 2009, Disponível em: <http://marte.dpi.inpe.br/col/dpi.inpe.br/sbsr@80/2008/11.18.01.38/doc/779786.pdf >. Acessado em: 20 jan. 2011.

PINHEIRO, G. M; AMORIM, M. C. C. T. O estudo de clima urbano em cidade de pequeno porte no oeste paulista. 2007. <http://www.geo.ufv.br/simposio/simposio/trabalhos/trabalhos_completos/eixo 8/026.pdf .>. Acesso em: 20 nov. 2011.

ROCHA, H. M. et al.. Variabilidade das temperaturas e conforto térmico em JataíGO. In: CONGRESSO DE PESQUISA, EXTENSÃO, 4, 2007, Goiânia. Anais... Goiânia, p. 497-498: 2007. CD- ROM.

SANTOS, M. dos S. VIDEIRA, S. L. A reprodução do solo urbano: um estudo breve sobre a verticalização de Cascavel/PR. ENCONTRO NACIONAL DOS GEOGRÁFOS, 16, 2010, Porto Alegre. Anais eletrônicos... Porto Alegre: 2010. Disponível em: http:// www.agb.org.br/evento/download.php?idTrabalho. Acesso em: 15 abr. 2012.

SILVA, L. T. Caracterização do clima urbano de Penápolis- SP. 2000. 88 f. Monografia (Bacharel em Geografia). Universidade Estadual Paulista, UNESPPresidente Prudente-SP, 2000.

SILVA, M. R. Desvelando a cidade: segregação socioespacial em Jataí - GO. 2009. 205 f. Tese (Doutorado em Geografia). Instituto de Estudos Socioambientais, Universidade Federal de Goiás, Goiânia, 2010.

SCOPEL, I.et al. Escoamento superficial da água na Microbacia do córrego do Sapo, em Jataí- GO, Revista do Departamento de Geografia de Geografia. Rondonópolis-MT: UFMT, 2002, v. 2 n. 2, p.117-125. 
SOUZA, M. B. Influência de lagos artificiais no clima local e no clima urbano: estudo de caso em Presidente Epitácio(SP).2010. 200 f. Tese (Doutorado - Programa de Pós- Graduação em Geografia Física) - Faculdade de Filosofia Letras e Ciências Humanas, São Paulo, 2010.

TUCCI, C. E. M. Usos e impactos dos recursos hídricos. In: MENDES, C. A; TUCCI, C. E. M. (Orgs). Avaliação integrada de bacia hidrográfica. Porto Alegre: 1997. p. 100-109.

VIANA, S. S. M. AMORIM, M. C. C. O clima urbano de Teodoro Sampaio/SP: episódios de verão. Revista Brasileira de Climatologia, Presidente Pudente: ABClima, n. 5, v. 5, p. $41-53,2009$. 